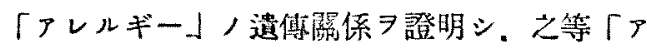

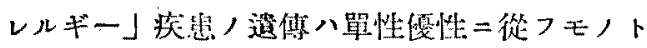

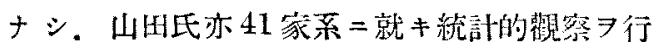
ヒそフ追證シ「「ア」性疾患，墢現二各個體，

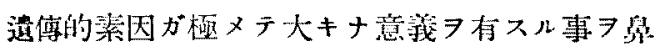
「アレルギー」ラ發端トシテ解朋シタ。一般二 我々八環境, 影響, 加ハッタ表現型ヨ通ジテ遗 傅因子テ知ルモノデアルガ，個帽表表現八環境 人影響ヨリモ寧口遗傳的影響ニヨリ强ク左右サ レル事ノ多1事八数多/例證=ヨリ證朋スル事 ガ出來ル。疾患=就テモ等性二䌡過スルモ， リ慢性二經過スル疾患二特二其傾向が强ク認メ ラレル事八結核性素因ノ存在二照シテモ容易二

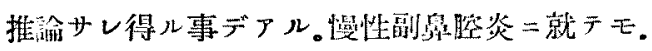

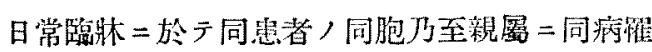

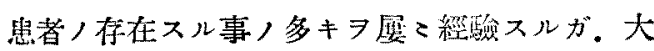
數, 家系 7 精密調查之慢性副臬腔炎卜遗傅的素 因聯關习究メタルモノが多ドナイ。そハーツ

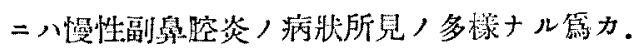
调人=ヨリ同疾霓存在，自覺缺如スル事がフリ 又從來慢性副壆腔炎，原因卜記戴サv，又思考 サレタ誘發疾患ノ多岐ナルコト等，签。同疾患 ，家系調查が極又テ困難ナル事二基因スルモ， ト考へラレル。慢性副學腔炎，大部分八急性炎 症，慢性化卜看做サレテ居ルノデアルガ．急性

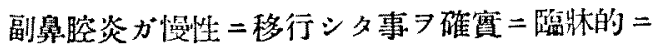
觀察ス几事八困難ナ事デアリ。臨师的二八寧口

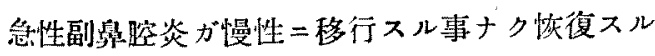
場合 7 多ク緸驗シ。慢性症二於テ八㭧者自身モ 多其發生時期. 爿態 7 適確二答へ得ナ1 热

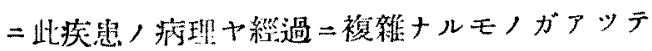
未ダ閵明七ラレテ居ナイ事ヨ感ズルノデアルガ 鬼モ们何故一ツ, 群が急性カラ慢性二移行シ。
他，群が笖性，狀態カラ道チ二惔復スルノデデ ル力。勿諭舅腔内，解剖學的條件力。或程度之 二關係，存スル事八荐へ得ラレルカ。副鼠腔粘

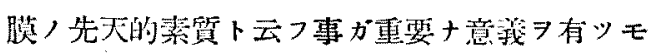
ノデハアルア1カ。而シテ此閌題，究明二八造 傅關係习調尘スル事がーツ, 方法デアル。ソコ デ私、主トシテ虔應病院耳鼻咽喉科二於テ鼻鏡

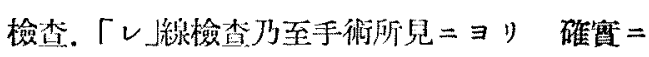

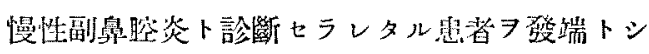
テ家系調查ヨ゙行ヒ。調楂家系中未完成ナルモ， ７除キ比較的完全二調楂心得夕59 芜系二就キ 統計的観祭习行ッ夕。調查方法八全管族員個夕 二特別二作整セル調查表二答ヨ記入セシメテ豫 診トナシ 健否二拘ラズ全管系员习适接㫨鏡檢 查シ。检皆不可能ナル保件ニアル第族員八調查 票=ヨリ罚患ノ存否 $习$ 制定シタ。1) 投端者 59 名小雨視ノ內一力或八兩方二同疾孯习認メタル モ４9例。認メザルモ，10例(但シ此 10 例中

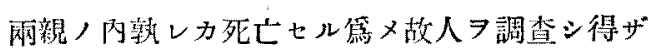
リシモノ 7 例 同病出現算八 $83 \%+4.9 \%$ 。2) 丽親,中八一方 が睢㭧者ナル時其子徏二於ケル舁者八出現率 八48.3土4.1\%。3)兩親共羅䍐者ナ：几時其子供 =於ケル患者出現率八79.3土6.2\%。以上

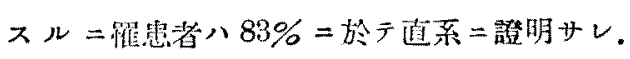

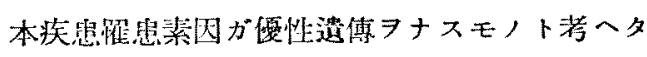
ル場合，理論值卜極メテ近似スル。

\section{7. 前頭洞覦外手術二於ヶル罳前頭} 交通路ノ塽寉ヨ防グエ夫ニ就テ

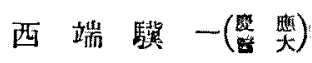

私八十數年爽副思腔炎，手衔的療法，研究=

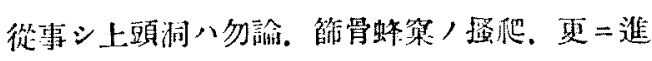

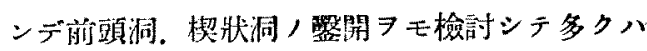


2 洞. 必要アラパ 3 洞. 場合ニョッテハ全洞ス ラモ之ョ一次的乃至二次的＝開放ス儿迄二到ツ 夕。而シテ之ア行フニ㗬ツテ主トシテロ腔法卜 鼻內法トヨ組に合七タ。例シ之デハ成績八必ズ シモ理想的ト八言七難イノデ．時二八更二舅外

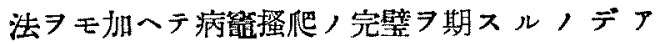

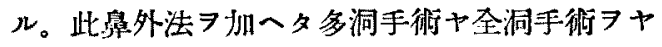
ツタ場合八手衍的療法トシテ最モ徽底シタモ， デアリ 從ッテ後療法ニ常ツテ術創ノ清潔ナル 事中治癒緸過，順調ナル事・理想=近イモノガ アル。處が禹多ノ手術例フ重ネテ居儿裡二時々 一大障碍 $=$ 當ツタノデアル.夫レハ手術 $=$ 際シ テ設ケタ鼻前頭交通路ガ解剖的異常二災サレテ 閉鎖シ易ク前頭洞，治瘾が妨ゲラレル事デアッ 夕。之等，多洞手術. 全洞手術 $=$ 就テ八其他再 感染/場合，問題ヤ。揳狀洞／治瘜困難，場合 等ト云フ問題モアルガ. 之二就テハ他日述べタ 1。私》鼻前頭交通路，狹管乃至閉鎖八前頭洞

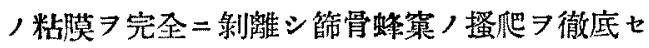
シメレバ起リ得ナイト考へタ時期ガアル。事實 大坻ノ場合之ハ葚理デアッタ。夫レ故搔爬ノ徹 底八確カニーツノ進步ニ八相違ナイ。一般二ハ

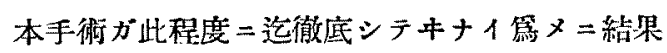
ガ思ハシクナイ事ガ多イ 夫レ八手街ノ經驗が 足リナイ䉆メデアルガ. 假令熟練シテモ正中前 頭㓊卜云つ解剖學的異常，伏兵／䉆又=失敗又 ル事がフル。夫レデ八之等，難㸃ヨ征服スレバ 鼻外法八モウ心眠ハナイカト云つト然㥞八行カ ナイ。ドウニモナラナイ解剖學的耀照二賞面 ル事ガアル。夫レ八前頭阔が非常二閶濶ナノ= 堭前頭交通路ガドンナ二庶クシテモ狹イモノシ カ作レナ1場合ダ，斯ウ云つ手術例デ八前頭洞 ガ癒り切ラナイ裡二皇前頭交通路が肉茅デ塞が
リ結局緳痕化シテ仕舞 フ・ソシテ街後間モナク 或八数年後二前頭洞ノ障碍ヨ現ハシテ柬儿。斯 ウ云フ例二遇ツテ苦シムト舀外法ノ適示 ニセザルラ得ナクナル。篩骨蜂巢，鼻外手術モ 同樣, 關係二置カレル。斯ウ云フ難物二對シテ ハドウ云フ手段フ講ジタラョイカト云フ事が賞 然研究題目ニナツテ來ル。其處デ文献シ調ベテ 見ルト歐羅巴/此方面/大家ガ大分苦心シテ居

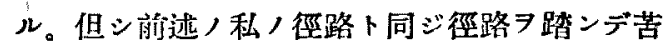
心シテ居ルノカドウカハ判ラナイ，別途ノ考へ カラデアルカモ知レナ1。夫レハ別トシテ此鼻 前頭交通路が塞がラナ1樣=工夫シテ居几專門 家トシテ Hajek, Seifert, Bárány, Uffenorde 7 擧方ル事が出來夕。Hajek，鼻外切創 7 哕開シ タマン上皮 ト云フ方法八具髁的二良ク理解出來ナイト理論 上カラモ賛成出來ナイ點がアルノデ追試シナカ ッタ。Seifert 法八數例二追試シタ。處ガ鼻前 頭交通路, 中へ「チールシュ」植皮術习行フ事 八種々，困難ガアッテ勍レモ失敗二終ッタ。其 方法 7 圖 =ヨッテ說明シ困難ナル點 $\ni$ 具體的 $=$ 述べテ見タ1 要スルニ本法八餘程技街 7 要 $ス$ ルシ日本人，鼠デハ然理デナイカト感ジ夕。其 處デUffenorde 法ア追試シテ見タ。處が此原著 ，簡單ナ圆卜說明デ方法殊=粘膜瓣,作り方

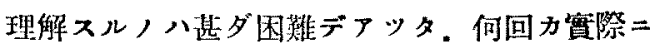

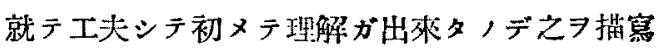
シテ䈯イタカラ圆說シテ見タイ Uftenorde， 原著ヨリハズット判り易イッモリデアル。夫レ カラ此方法习行フノニモウーツ躊躇サ七ル點方

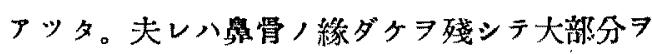
釗除スルノデアルカラ術後此部ガ凹陷シテ醜形 ヨ是シハシナイカト心眠サレル事デアツタ。追 
試ノ結果桇外ニモ少シモ其䚋念ガナイ事ヨ知ツ タフデ 夫レ二就テモ述へテ見タイ俶シ何ン

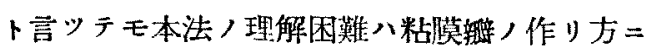
アルカラ其點ア特二說明シタイト思つ。而シテ

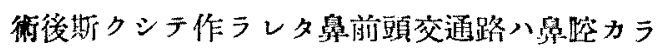
覞察シテドウ云フ風二認識サレルカ。そ二關シ テハUffenorde八充分ナ說明 シシテ居ナイカラ 私ハを二就テモ回說シヤウ。他，方法ニヨツラ 作ツタ交通路卜八可成り港ナツタモノデアル事 ヨ知ツタノデァル。私八Uffenorde 法二就テ大 鰽满足シテ居ルガ．追試ノ水ダ不充分ナ點が何 處ニアツテ將爽佮木不安二思ツテ居ル點が何デ アルカラ附言スルツモリデフル。Bárány 法ハ 末ダ追試シテ居ナけ。或八其必要がナイカトモ 思フ。簡單二紹介スルニ止メラ置ク事ニスル。

迡加小田大吉 [阔山照大]。私方訪問シテ居タ比 ロフェノルデ数授ハ前行洞二對シテャンゼンノ庄式

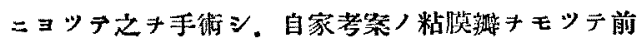
頭洞鼻些艾通磪保シャゥトシテ居タ。其方法》 「シュタンッメ」キ用とテ先ッ洪骨キ破りコレョタ

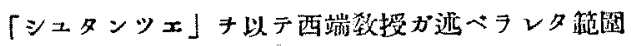
二於テ骨斗除ク。郎千下方八上罚前頭突起及ビ荤骨

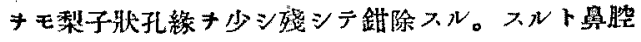

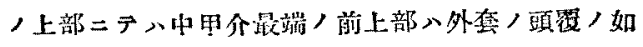

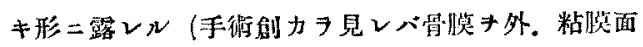
*内ニシテ）コレキ上キ切り分タテ丙外，2班トシ 外侧ノモノハコレキ源骨改ビ前頭等起上部キ除かレ

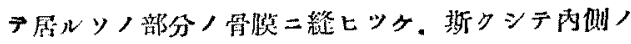

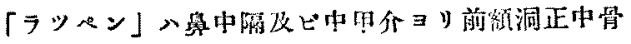

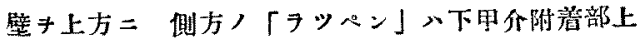

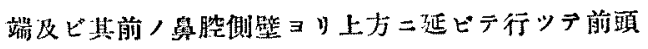

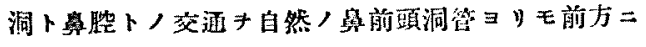

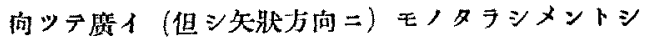

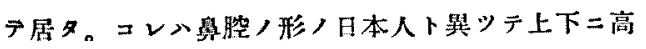
イ西洋人二於テハ之心容易二山柬ルノキ見ナが・。 日本人デハムツカシイ。

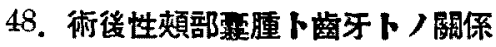

森本正紀(裂留) 術後性頓部霓腫卜鑑別 7 要スルモノ、第一位

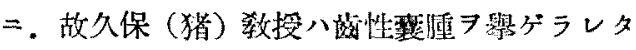
ガ. 貫際腄脹が顂部，下部二現ハレタ場合二八

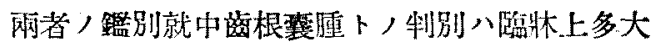

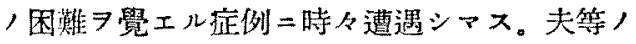
多クハ手術所見．組織所見习呤味スル卜爁別八 可能デアリマスガ.中ニハ手術シテ見テモ。組織 的ニ精查シテモ判定ノ殆ド不可能ナ提例 ナラズ經驗シ。其結果從柬色タト諭議サレラン

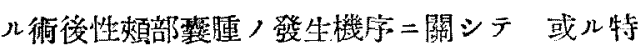

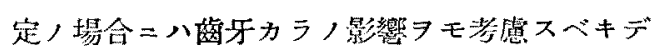
ハナイカト考へルニ至ッテキル次第デ. 過去 2 年間二經驗シタ術後煩部裂腫症例/中. 落牙病 變ト，因果關係习思ハシメル4例フ總括シ(一 覽表幻燈).二三，早見ヨ中上ゲャス。第 1 例卜

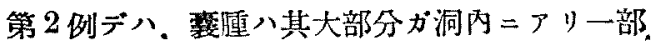

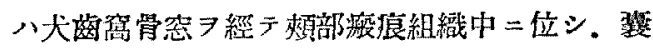

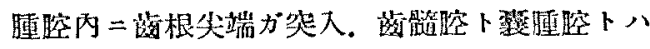
直接交通シテキル(「レ」線像幻燈)。此手術所 見(「スケっチ」幻燈)カラ考へアスト正シク落

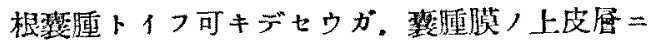
圆柱上皮或八氈毛上皮习具有スルコト八注意

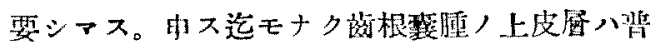

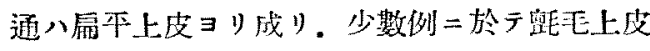
乃至圓柱上皮デ形成七ラレマス。斯カル場合屁 平上皮モ亦共二認メラルラ通例トシ。其際望毛毛 上皮が上顎洞粘膜二由來スルコトハ異諭つリマ センガ. 其意䉝二就テ八完全二歸一シタ見解八

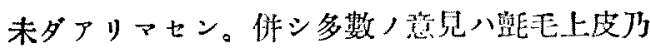
至圆柱上皮，發現习二次的附加現像卜解シテキ ル。演者モ此見解二從ヒマス。偖テ問題トシテ 